\title{
BAHAN AJAR MATRIKULASI PENDIDIKAN BAHASA ARAB
}

\author{
Saproni Muhammad Samin \\ Universitas Islam Riau, Jl. Kaharuddin Nst. No. 113, Pekanbaru, Riau, Indonesia \\ Email: Safroni.ahmad@edu.uir.ac.id
}

\begin{abstract}
The purpose of this research is to find out the essential educational competencies that must be understood by new students which are the demands of the curriculum on Education of Arabic Language of Universitas Islam Riau (UIR) and determine matriculation learning materials. This research used the Qualitative Research Method within photographic technique functioned as initial research to collect data to create the education framework of learning material mapping. Data collection technique is done through literature study and interviews on to lecturers in language skill courses in Education of Arabic Language of UIR with a total of 5 people. This research concluded the learning materials in matriculation for Education of Arabic Language of UIR can be formulated into a package of methods presented in the form of 8 (eight) practical steps.
\end{abstract}

Keywords: Learning Materials, Matriculation, Education Of Arabic Language

\begin{abstract}
ABSTRAK
Tujuan dari penelitian untuk mengetahui kemampuan dasar yang harus dimiliki mahasiswa baru yang menjadi tuntutan kurikulum Prodi Pendidikan Bahasa Arab Universitas Islam Riau (UIR) dan menentukan bahan pembelajaran (Learning Materials) matrikulasi. Metode yang digunakan dalam penelitian ini adalah Metode Kualitatif dengan teknik deskriptif yang difungsikan sebagai penelitian awal untuk mengumpulkan data dalam rangka pemetaan materi. Sementara itu, teknik pengumpulan data dilakukan melalui Studi Pustaka dan wawancara terhadap dosen-dosen pengampu mata kuliah kemahiran bahasa di prodi PBA UIR sebanyak 5 orang. Berdasarkan penelitian yang dilakukan diperoleh simpulan bahwa bahan pembelajaran matrikulasi Pendidikan Bahasa Arab UIR dapat dirumuskan ke dalam satu paket metode yang disajikan dalam bentuk 8 (delapan) langkah praktis.
\end{abstract}

Kata Kunci: Bahan Ajar, Matrikulasi, Pendidikan Bahasa Arab

\begin{tabular}{|c|c|c|c|}
\hline FIRST RECEIVED: & REVISED: & ACCEPTED: & PUBLISHED: \\
15 October 2019 & 15 January 2020 & 15 February 2020 & 14 April 2020 \\
\hline
\end{tabular}

\section{PENDAHULUAN}

Pengajaran bahasa Arab sebagai mata pelajaran atau suatu mata kuliah dengan pengajaran bahasa Arab yang disajikan khusus dalam suatu program studi pendidikan bahasa Arab mempunyai perbedaan. Salah satu perbedaannya adalah kesiapan belajar peserta didik atau mahasiswa dan modal dasar mereka dalam kemampuan bahasa Arab baik bahasa Arab sebagai ilmu maupun sebagai skill (maharah).

Hal itu, belum lagi kendala yang dihadapi oleh program studi (prodi) pendidikan bahasa Arab, seperti input dengan latar belakang pendidikan umum yang tidak mempunyai cukup pengetahuan dasar tentang bahasa Arab (Hidayat, N.S.( 2012). 
Oleh karena itu diperlukan adanya program matrikulasi karena matrikulasi bahasa cukup efektif (Kaptiningrum \& Mubarok, 2017) dan sangat penting dalam persepsi mahasiswa (Syahadati, Rodhi, \& Sari, 2018) dalam membekali mahasiswa baru tentang pengetahuan dan kemampuan dasar bahasa Arab sehingga mendapatkan bekal dan kesiapan untuk beradaptasi dan mengikuti pembelajaran mata kuliah, khususnya yang bersifat skill atau keterampilan. Hal ini menjadi penting untuk menghindari demotivasi mahasiswa dalam belajar bahasa Arab (Islam, 2015).

Matrikulasi menurut Kamus Besar Bahasa Indonesia (KBBI) daring adalah "hal terdaftarnya seseorang di perguruan tinggi." Yang dimaksud dalam penelitian ini adalah program akselerasi pengetahuan dan kemampuan dasar mahasiswa tentang bahasa Arab. Tujuan diselenggarakannya matrikulasi adalah guna penyetaraan kompetensi mahasiswa baru dengan pengetahuan dan kemampuan dasar bahasa Arab. Yang menjadi peserta adalah mahasiswa yang tidak memenuhi nilai pengetahuan dan kemampuan standar yang telah ditentukan oleh prodi pendidikan bahasa Arab. Tujuan dari artikel untuk mengetahui kemampuan dasar yang harus dimiliki mahasiswa baru yang menjadi tuntutan kurikulum prodi pendidikan bahasa Arab Universitas Islam Riau (UIR) dan menentukan bahan pembelajaran (Learning Materials) matrikulasi.

\section{PENGERTIAN, FUNGSI DAN TUJUAN MATRIKULASI}

Kata Matrikulasi dalam Kamus Besar Bahasa Indonesia (KBBI) adalah "hal terdaftarnya seseorang di perguruan tinggi." Matrikulasi merupakan kegiatan yang dilakukan untuk menyikapi adanya kesenjangan yang terjadi antara mahasiswamahasiswa baru dalam hal pengetahuan dan keterampilan dasar. Matrikulasi tersebut berfungsi untuk menyiapkan kemampuan awal yang diperlukan oleh mahasiswa baru sehingga mereka mampu beradaptasi dan mengikuti proses kegiatan belajar mengajar. Jadi program matrikulasi ini diperlukan manakala ada peserta didik yang belum memenuhi kecukupan pengetahuan dan keterampilan dasar yang dipersyaratkan oleh institusi, atau lembaga tertentu. Tujuan dari program matrikulasi ini adalah sampai pada satu level yang sama yang memuat seperangkat pembelajaran yang mengandung pengetahuan dan skill yang dibutuhkan oleh peserta didik (Kemendikbud, 2014).

$$
\text { Program matrikulasi ini }
$$

diselenggarakan melalui beberapa kegiatan. Kegiatan pertama adalah diskusi tentang matrikulasi dengan para mahasiswa peserta, fungsinya agar para peserta bisa secara mandiri mampu menemukan informasi melalui sumber-sumber yang melimpah di sekitar mereka seperti internet, buku dan melakukan diskusi dengan pihak-pihak yang mempunyai kompetensi di bidang yang dibutuhkan peserta. Misalnya pada satu jam pertama dilakukan diskusi dan pemahaman serta penyadaran pentingnya belajar mandiri, kemudian pada jam selanjutnya meminta kepada peserta untuk mempresentasikan dan menyampaikan bahan diskusi untuk didiskusikan secara bersama. Adapun model ini mempunyai kelebihan dari sisi bahwa siswa yang tergabung dalam suatu kelompok tertentu akan memperoleh pengalaman dan informasi secara rinci dan detail melalui proses membaca langsung. Setelah itu peserta 
matrikulasi akan menyampaikan pertanyaan demi pertanyaan.

Hal ini menunjukkan bahwa peserta mulai memahami permasalahan dan mereka sudah mulai melakukan upaya untuk masuk pada pengetahuan dan kemampuan yang dibutuhkan. Bisa disebutkan bahwa program matrikulasi ini berfungsi untuk mempertajam kepekaan analisis peserta dan belajar untuk menarik sebuah kesimpulan melalui proses ilmiyah. Diskusi yang dilaksanakan dalam program ini, dengan cara peserta mendiskusikan, menyampaikan, bertanya, menjawab, memahami dan menyimpulkan. Diharapkan dengan menggunakan model ini akan terjadi efektivitas belajar. Peserta matrikulasi mengalami sendiri proses scientific sehingga nilai kognitif yang dihasilkannya akan berkualitas tinggi. (Sunaiyah, 2018)

Program matrikulasi menghasilkan dampak positif terhadap proses memunculkan bakat dan minat mahasiswa baru yang bisa jadi ketidakmampuan mereka mengikuti perkuliahan bersama kelas reguler, akan melahirkan sikap imperior dan rendah diri. Menurut Barokatunnisa (2017) dengan diadakan program matrikulasi yang dilakukan di MAN 1 Boyolali telah disimpulkan berpengaruh terhadap peningkatan minat siswa dan prestasi belajar bahasa Arab serta Pelaksanaan matrikulasi sangat bermanfaat bagi siswa karena dengan matrikulasi minat siswa terhadap bahasa arab meningkat sehingga berpengaruh positif terhadap hasil belajarnya.

Menurut Hartati (2017) dalam penelitian yang dilakukan untuk mengukur respon mahasiswa terhadap program matrikulasi, menunjukan bahwa 53\% mahasiswa setuju dengan diadakannya matrikulasi. $73 \%$ menganggap materi matrikulasi telah sesuai dengan kebutuhan. Sebesar $61 \%$ mahasiswa memahami atas materi yang telah diberikan saat matrikulasi. Berkenaan dengan suasana kelas, sebesar 53\% mahasiswa menganggap suasana kelas menyenangkan di saat pelaksanaan matrikulasi. Dengan kata lain bahwa program matrikulasi mendapatkan respon sangat baik dari mahasiswa.

\section{MODEL MATRIKULASI}

Model yang digunakan oleh beberapa lembaga pendidikan masih bersifat konvensional. Model konvensial tersebut artinya masih menggunakan model pedagogi, yaitu bertumpu pada pendidik (teachercentered) atau subject based. Jika model ini yang diberlakukan, beberapa kelemahan yang muncul misalnya peserta tidak memiliki kesiapan yang memadai tidak mempunyai inisiatif dalam pengembangan ilmu, serta hanya bertumpu pada apa yang disajikan oleh pendidik dan hanya ilmu yang disampaikan di ruang kelas.

Selain dari metode konvensional di atas, ada model lain yang lebih baik untuk penerapannya, yaitu metode student-centered, misalnya dengan menggunakan peta konsep sebagai salah satu metode pembelajaran. Dengan metode peta konsep dengan pendekatan student centered pembelajaran akan lebih terarah dan terstruktur lebih baik. Pendekatan student centered diharapkan bisa memenuhi sasaran pembelajaran dan kemampuan yang diharapkan (Wulandari, E., Hapsari, R.A.F. and Ariany, 2013).

\section{BAHAN AJAR}

Bahan Ajar atau juga disebut sebagai bahan pembelajaran atau sering disebut 
dengan learning materials merupakan suatu perangkat pembelajaran yang mengandung materi atau subtansi pelajaran yang didesain secara sistematis dan terukur yang menggambarkan bangunan kompetensi secara utuh yang harus dikuasai oleh peserta dalam program matrikulasi. Maksud dan tujuan bahan pembelajaran ini, bisa menjadi pegangan bagi peserta untuk melihat kompetensi yang dibutuhkan secara terpadu dan utuh. Berdasarkan hal tersebut, hal ini menjadi pemahaman semua akan perlunya para pendidik memiliki kompetensi dalam mengembangkan bahan ajar yang sesuai dengan ketentuan-ketentuan, sehingga materi mampu tersampaikan dengan baik, dan akhirnya pesertapun memiliki aktivitas belajar yang baik pula (Hernawan, A.H., Permasih, H. and Dewi, 2012).

Sungkono dkk dalam (Hernawan, A.H., Permasih, H. and Dewi, L. (2012)) Menambahkan bahwa bahan pembelajaran adalah suatu perangka bahan yang mengandung materi atau isi pembelajaran yang dirancang untuk mencapai tujuan pembelajaran. Bahan ajar hendaklah mengandung materi, pesan atau isi mata pelajaran yang berupa fakta, ide, konsep, prinsip, teori, atau kaidah yang termuat dalam mata pelatihan sesuai disiplin ilmu serta informasi-informasi lain dalam pembelajaran. Dasar batasan tersebut, dapat dimengerti bahwa yang dimaksudkan dengan bahan pembelajaran adalah rancangan suatu materi atau isi pelatihan yang dimunculkan dalam bentuk benda atau bahan yang dapat digunakan untuk belajar siswa dalam proses pembelajaran.

Menurut Hernawan, A.H., Permasih, H. and Dewi, (2012) ada dua model bahan pembelajaran, Pertama, Bahan ajar yang sengaja dirancang secara lengkap. Maksudnya adalah bahan ajar mengandung semua komponen-komponen yang dibutuhkan oleh suatu bahan pembelajaran meliputi; tujuan pembelajaran, kompetensi yang hendak dicapai, macam-macam kegiatan yang harus diikuti oleh peserta, materi pembelajran yang dirancang secara sistematis, adanya ilustrasi atau media peraga pembelajaran, latihan serta tugas, evaluasi dan umpan balik. Contoh dari model ini misalnya; audio pembelajaran, modul pembelajaran, pembelajaran berbasis komputer, video pembelajaran, pembelajaran berbasis web/net. Kedua, Bahan Ajar yang sengaja dirancang tidak lengkap. Maksudnya adalah bahan pembelajaran yang didesain tidak lengkap atau terbatas pada komponenkomponen tertentu. Misalnya dalam bentuk sumber belajar, alat peraga, media pembelajaran yang digunakan sebagai alat bantu manakala tenaga pendidik dan peserta menyelenggarakan kegiatan pembelajaran. Contoh model ini seperti belajar dengan transparansi, pembelajaran dengan berbagai alat peraga, belajar dengan buku teks, globe, peta, model kerangka manusia dan lain sebagainya.

Sementara itu bahan pembelajaran dari sisi jenisnya bisa diklasifikasikan ke dalam dua kelompok. Pertama, printed materials; handout, buku pelajaran, modul, programed material. Kedua, elektronic materials; CD interaktif, radio, tv.

\section{TUJUAN PENGAJARAN BAHASA ARAB}

Menurut Rusydi Ahmad Thuaimah dalam (Ahmad, 2018) bahwa tujuan pengajaran Bahasa Arab untuk penutur nonarab dibagi menjadi dua; tujuan umum dan tujuan cabang. 
Adapun tujuan umum pengajaran bahasa Arab adalah; Mampu berbahasa Arab sebagaimana native-speaker bahasa Arab berbahasa atau minimal mendekatinya, mengenal karakteristik bahasa Arab yang membedakannya dengan bahasa-bahasa lainnya baik dari segi fonem, morfem, sintaksis dan semantiknya, mengenal kebudayaan Islam dan arab serta mengenali karakteristik orang arab, Masyarakat dan lingkungan sosial arab.

Tujuan cabang pengajaran bahasa Arab terdiri dari 5 (lima) bagian; kemahiran mendengar, kemahiran berbicara, kemahiran membaca dan kemahiran menulis, serta kaidah-kaidah bahasa Arab.

Untuk kemahiran mendengar terdiri dari 23 (duapuluh tiga) item, sebagai berikut.

1. Mengenal fonem arab dan membedakan antara satu dengan yang lainnya secara signifikan.

2. Memahami percakapan bahasa Arab yang didengar dengan intonasi natural dalam batasan kosa kata yang telah dipelajari.

3. Memilih apa yang harus didengar dan diperhatikan.

4. Mampu menentukan pokok-pokok pikiran utama.

5. Mampu membedakan antara pokok pikiran utama dan sekunder.

6. Mengenal harokat panjang dan pendek serta membedakan di antara keduanya.

7. Mengenal suara Tasydid dan Tanwin dan mampu membedakan keduanya.

8. Mengetahui hubungan antara simbolsimbol fonem arab dan tulisan.

9. Membedakan antara kenyataan dan pendapat-pendapat melalui konteks percakapan biasa.
10. Mengikuti percakapan dan mengetahui hubungan di antara sisi-sisinya.

11. Mengetahui kebiasaan mendengar dan etika-etikanya.

12. Membedakan antara fonem yang berdekatan dalam pengucapan dan fonem yang mempunyai kemiripan.

13. Mengetahui titik kemiripan dan perbedaan antara fonem arab dan fonem bahasa awal.

14. Mendengarkan bahasa Arab dan mampu memahaminya tanpa terhalang oleh kaidah-kaidah bahasa Arab.

15. Mengetahui kontradiksi dari sisi-sisi percakapan yang didengar.

16. Mengetahui perubahan makna yang dihasilkan dari perubahan bangunan morfem.

17. Beradaptasi dengan intonasi nativespeaker:mengambil pokok pikiran dari ritme pembicaraan yang cepat ataupun lambat.

18. Mengambil sisi kemiripan dan perbedaan dari suatu pendapat.

19. Membayangkan peristiwa-peristiwa yang disampaikan oleh pembicara.

20. Mampu mengambil kesimpulan dari suatu pengantar yang didengar.

21. Membedakan nada penekanan dan ungkapan-ungkapan yang mengandung emosional.

22. Menggunakan konteks dalam memahami kosa-kata baru.

23. Mengetahui apa yang ingin diungkapkan pembicara, melalui intonasi dan nada biasa.

Untuk kemahiran berbicara terdiri dari 23 (duapuluh tiga) item juga, sebagai berikut.

1. Mampu mengucapkan fonem arab dengan benar. 
2. Membedakan dengan jelas antara pengucapan fonem yang mempunyai kemiripan.

3. Membedakan dalam pengucapan antara harokat pendek maupun panjang,

4. Mampu menggunakan intonasi dan nada pengucapan bahasa Arab yang bisa diterima oleh native-speaker bahasa Arab.

5. Mengucapkan dengan benar fonemfonem arab yang mempunyai kedekatan.

6. Mengungkapkan pikiran menggunakan formulasi sintaksis yang sesuai.

7. Menggunakan ungkapan-ungkapan yang sesuai dalam setiap kesempatan yang berbeda-beda.

8. Menggunakan ungkapan basa-basi, ucapan selamat dengan menggunakan ungkapan yang diterima oleh budaya arab.

9. Menggunakan aturan yang benar dalam menyusun (tarkib) kata bahasa Arab ketika berbicara.

10. Mengungkap dengan pilihan kata yang tepat saat dihadapkan pada pilihanpilihan kata yang mempunyai persamaan makna.

11. Menyusun pokok pikiran secara runtut.

12. Mengungkapkan pokok pikiran dengan kadar bahasa yang tepat, tidak terlalu panjang yang mengakibatkan bosan, tidak pula terlalu singkat.

13. Berbicara secara bersambung dan berhubungan dalam rentang waktu yang bisa diterima, yang bisa menguatkan kepercayaan diri dan kemampuan menghadapi lawan bicara.

14. Mengucapkan kata yang bertanwin dengan benar serta mampu membedakan antara tanwin dengan yang lainnya.

15. Menggunakan isyarat, gestur dan gerakan tubuh untuk membantu menyampaikan ide dan pikiran.

16. Berhenti untuk masa waktu yang sesuai saat berbicara, saat mengulangi pikiran atau menjelaskannya, dan mengevaluasi formulasi suatu kata.

17. Merespon apa yang didengar dengan respon secara otomatis.

18. Fokus pada makna pembicaraan bukan pada bentuk bahasa.

19. Mengubah alur pembicaraan dengan lihai, saat kondisi membutuhkan hal tersebut.

20. Menceritakan pengalaman pribadi dengan cara yang menarik dan sesuai.

21. Menyampaikan khutbah pendek namun mencakup semua unsur yang diperlukan.

22. Mengelola suatu diskusi dalam topik tertentu dan mampu mengambil kesimpulan dari ide dan pendapat para peserta diskusi.

23. Mengatur percakapan via telepone dengan native-speaker bahasa Arab.

Untuk kemahiran membaca terdiri dari 23 (duapuluh tiga) item, sebagai berikut.

1. Membaca teks arab dari kanan ke kiri dengan mudah.

2. Menghubungkan simbol suara yang tertulis dengan gampang dan mudah.

3. Mengetahui kata dan sinonimnya.

4. Mengetahui makna-makna baru dari satu kata.

5. Analisis teks bacaan kepada bagianbagian dan mengetahui hubungan di antaranya. 
6. Mengikuti pikiran yang terkandung dalam teks dan menjaganya selama masa membaca.

7. Menghasilkan makna umum dari teks bacaan.

8. Membedakan antara pokok pikiran dan pikiran sekunder dalam teks bacaan.

9. Mengetahui perubahan makna dalam perubahan susunan kata.

10. Memilih rincian yang mendukung atau melawan pendapat tertentu.

11. Mengetahui makna kosa baru dari konteks.

12. Sampai pada makna yang terkandung dari balik teks.

13. Beradaptasi dengan ukuran kecepatan dalam membaca tergantung pada tujuan kenapa ia membaca.

14. Menjaga makna saat membaca cepat dan tanpa mengorbankannya.

15. Menggunakan kamus, mu'jam dan ensiklopedia arab.

16. Membedakan antara kenyataan dan opini dalam teks bacaan.

17. Detail dalam gerakan mengulang dari akhir baris ke awal baris yang seterusnya.

18. Menyingkap titik-titik kemiripan dan persamaan antara kenyataan yang terbentang.

19. Mengklasifikasikan kenyataan mengaturnya dan membentuk ide di dalamnya.

20. Representasi antara makna dan kecepatan yang sesuai saat membaca dengan keras.

21. Meresume dengan bagus pikiran yang terkandung dalam teks.

22. Ketepatan dalam pengucapan huruf dengan tetap menjaga harokat i'rob (akhir kata) tatakala membaca dengan keras.

23. Menggunakan pengantar, indeks, daftar isi, catatan kaki, pasal, pangkal paragraf, petunjuk cetakan, tabel, grafik, indeks nama orang dan tempat, dan kamus yang terdapat di akhir buku.

Untuk kemahiran menulis terdiri dari 22 (duapuluh dua) item, sebagai berikut.

1. Memindahkan dengan benar kata yang tertulis di papan tulis atau buku cetak.

2. Mengenal cara penulisan huruf hijaiyah dalam segala bentuk dan letaknya.

3. Membiasakan menulis dari kanan ke kiri.

4. Menulis kata bahasa Arab dengan huruf secara bersambung maupun terputus beserta kemampuan membedakan bentuk-bentuk huruf.

5. Kejelasan garis dan gambar huruf.

6. Akurat dalam menulis kata yang mempunyai huruf yang diucapkan tapi tidak ditulis, yang ditulis tapi tidak diucapkan.

7. Menjaga kaidah imla' dasar dalam penulisan.

8. Menjaga keselarasan dan keteraturan apa yang ditulisnya dengan bentuk yang sedikit memberi keindahan.

9. Menguasai ragam khat arab.

10. Menjaga kekhasan tulisan arab seperti mad, tanwin, tasydid.

11. Memperhatikan tanda baca saat menulis.

12. Meresume tema teks bacaan dengan benar.

13. Memenuhi unsur-unsur yang dibutuhkan saat menulis surat. 
14. Menerjemahkan pikiran dalam paragraf menggunakan kosa kata dan susunan yang sesuai.

15. Menulis cepat dan benar.

16. Membuat surat kepada kawan di momen tertentu.

17. Mensifati pemandangan alam dengan akurat dengan tulisan yang bisa dibaca.

18. Menulis permohonan pekerjaan tertentu.

19. Menulis laporan sederhana seputar masalah dan problematika tertentu.

20. Mengisi formulir pemerintah yang diminta.

21. Sensitif terhadap beragam situasi yang menuntut penulisan surat dengan tetap menjaga budaya arab.

22. Menjaga ketersesuaian antara huruf panjang dan luas dan ketersesuaian kata di kondisi dan dimensinya.

\section{METODE PENELITIAN}

Metode yang digunakan dalam penelitian ini Metode Penelitian Kualitatif. Teknik penelitian Studi Pustaka dan Wawancara. Pengumpulan data dilakukan melalui Studi Pustaka dan wawancara terhadap 5 orang dosen pengampu mata kuliah kemahiran bahasa di prodi PBA UIR, selama 2 (dua) bulan mulai dari bulan agustus dan september tahun 2019 M, di lingkungan Universitas Islam Riau Pekanbaru.

\section{HASIL DAN PEMBAHASAN}

Program studi (Prodi) PBA-UIR tergolong prodi baru, dioperasikan setelah mendapatkan izin operasional pada akhir Juli 2017, namun rancangan kurikulum 2017 sudah disesuaikan dengan Kurikulum Perguruan Tinggi (KPT) berbasis Kerangka
Kualifikasi Nasional Indonesia (KKNI). Hasil telaah kurikulum yang diberlakukan di Prodi PBA-UIR yang kemudian disebut dengan nama Kurikulum 2017, disertai dengan wawancara para dosen pengampu mata kuliah kemahiran bahasa (listening, speaking, reading, writing), jika mengacu kepada tujuan pembelajaran bahasa Arab yang dirancang oleh Rusydi Ahmad Thuaimah dalam (Ahmad, 2018) maka dapat disimpulkan bahwa kemampuan dasar mahasiswa baru Prodi PBA-UIR dikatakan bisa mengikuti perkuliahan mata kuliah kemahiran bahasa adalah sebagai berikut.

Kompetensi Dasar untuk Kemahiran mendengar; Mampu mengetahui fonem arab dan mampu membedakan diantara fonem arab tersebut secara signifikan, mampu memahami percakapan bahasa Arab dengan gaya tutur natural dalam batasan kosa kata yang dipelajarinya, mampu memilih apa yang seharusnya diperhatikan, mampu mengetahui harokat panjang dan pendek serta mampu membedakan diantara keduanya, mampu mengetahui tasydid dan tanwin serta mempu membedakan suara keduanya, serta mampu mengetahui hubungan antara simbol suara dan simbol tulisan.

Kompetensi dasar untuk Kemahiran berbicara (speaking); mampu mengucapkan fonem-fonem arab dengan benar, mampu membedakan pengucapan fonem-fonem arab yang mempunyai kemiripan, mampu membedakan pengucapan antara harokat yang panjang maupun pendek, mampu mengucapkan intonasi dan nada suara arab dengan cara yang bisa diterima oleh nativespeaker bahasa Arab, serta mampu mengucapkan fonem-fonem arab yang mempunyai kedekatan dengan cara yang benar. 
Kompetensi dasar untuk kemahiran membaca (Reading); mampu membaca teks arab dari kanan ke kiri dengan mudah dan enak didengar, mampu menghubungkan simbol-simbol suara yang tertulis dengan mudah, mampu mengetahui kosa kata-kosa kata baru dan sinonimnya, mengetahui artiarti baru dari satu kosa kata.

Kompetensi Dasar untuk kemahiran menulis; mampu memindahkan kata yang tertulis di papan tulis atau di buku khat dengan benar, mampu mengetahui tata cara penulisan huruf hijaiyah dalam bentuk dan tempat-tempatnya yang berbeda-beda, mampu membiasakan menulis dari kanan ke kiri, mampu menulis kosa kata bahasa Arab dengan huruf-huruf terpisah maupun tersambung serta mampu membedakan bentuk-bentuk hurufnya, mampu menulis dan menggambar huruf dengan jelas.

Pada aspek lain, kompetensi dasar untuk kaidah-kaidah dasar bahasa Arab; mampu menggunakan makrifah dan nakiroh, mampu menggunakan kata-kata tunjuk, mampu menggunakan kata ganti kepemilikan.

Hasil identifikasi kemampuan dasar yang harus dimiliki oleh setiap mahasiswa baru pendidikan bahasa Arab-UIR, maka bisa dirumuskan bahwa bahan pembelajaran bagi peserta matrikulasi bisa disajikan dalam bentuk 8 (delapan) langkah praktis, sebagai berikut; pertama, pengenalan huruf Hijaiyah beserta makhorijul hurufnya, dengan tujuan bisa mendengar, mengucapkan, membaca dan menuliskannya dengan baik dan benar serta mampu menghafalnya. Kedua, mengenalkan harokat dan sukun, dengan tujuan memberikan huruf vokal pada huruf-huruf konsonan arab serta bisa mendengar, mengucapkan, membaca dan menulisnya dengan baik dan benar. Ketiga, menyambung huruf dengan tujuan mengenal huruf yang bisa menyambung dan disambung dan huruf yang tidak bisa menyambung akan tetapi bisa disambung, serta perubahan-perubahan bentuk huruf di setiap tempat, serta bisa mendengar, mengucapkan, membaca dan menulisnya dengan baik dan benar. Keempat, mengenalkan huruf mad, dengan tujuan mengenal simbol untuk suara huruf yang dipanjangkan atau dipendekkan, serta bisa mengucapkan, membaca dan menulisnya dengan baik dan benar. Kelima, mengenalkan tasydid, dengan tujuan mengetahui simbol untuk suara huruf yang digandakan, serta bisa mengucapkan, membaca dan menulisnya dengan baik dan benar. Keenam, mengenalkan tanwin, dengan tujuan mengetahui simbol suara di akhir kata yang berbunyi an, in, un serta bisa mengucapkan, membaca dan menulisnya dengan baik dan benar. Ketujuh, mengenalkan Ta' Marbuthoh, dengan tujuan mengetahui simbol suara huruf $T a$ ' di akhir kata, serta bisa mengucapkan, membaca dan menulisnya dengan baik dan benar. Kedelapan, mengenalkan "Al", dengan tujuan mengetahui karakter kata bahasa Arab jika dimasuki "Al Qomariyah" dan " $A l$ Syamsiyah", serta bisa mendengar, mengucapkan, membaca dan menulisnya dengan baik dan benar.

\section{SIMPULAN}

Keragaman mahasiswa baru dari sisi kemampuan bahasa Arab merupakan tantangan yang harus dihadapi oleh manajemen program studi (prodi) Pendidikan Bahasa Arab yang masih tergolong baru, disebabkan input yang belum bisa diseleksi secara ketat. Matrikulasi bahasa merupakan solusi yang merupakan kegiatan yang dilakukan untuk menyikapi adanya 
kesenjangan yang terjadi antara mahasiswamahasiswa baru dalam hal pengetahuan dan keterampilan dasar. Untuk menentukan bahan pembelajaran matrikulasi, maka perlu diadakan identifikasi kemampuan dasar yang harus dimiliki oleh semua mahasiswa baru Pendidikan Bahasa Arab. Disimpulkan bahwa implikasi dan manfaat bahan pembelajaran matrikulasi Pendidikan Bahasa Arab UIR dapat dirumuskan ke dalam satu paket metode yang disajikan dalam bentuk 8 (delapan) langkah praktis kepada mahasiswa sebagai masyarakat atau komunitas akademis.

\section{DAFTAR PUSTAKA}

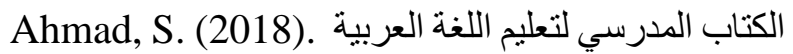
للناطقين بغير ها: أهميته، ووظائه، وأهداف تعليمها. Al-Manar, 1(8).

Barokatunnisa, R. (2017). Program Matrikulasi Bahasa Arab Sebagai Upaya Peningkatan Minat Dan Prestasi Belajar Siswa Kelas X Ipa MAN 1 Boyolali.

Hartati, M. (2017). Respon Mahasiswa Mengenai Pelaksanaan Matrikulasi Bagi Mahasiswa Baru Ikip PGRI Pontianak, 15(2), 243-252.

Hernawan, A.H., Permasih, H. and Dewi, L. (2012). Pengembangan Bahan Ajar. Bandung: Direktorat UPI.

Hidayat, N. S. (2012). Problematika Pembelajaran Bahasa Arab. Jurnal Pemikiran Islam, 37(1), 82-87.

Islam, A. M. S. (2015). Faktor Demotivasi Pembelajaran Bahasa Arab. Arabiyat: Jurnal Pendidikan Bahasa Arab Dan Kebahasaaraban, 2(1), 1-16. https://doi.org/http://dx.doi.org/10.15408 /a.v2i1.1511

Kaptiningrum, P., \& Mubarok, Z. (2017). Keefektifan Program Matrikulasi Bahasa Untuk Meningkatkan Kemampuan Speaking Mahasiswa Staibn Tegal. LINGUA: Journal of Language, Literature and Teaching, 14(1), 54. https://doi.org/10.30957/lingua.v14i1.240
KBBI. (n.d.). Matrikulasi. Retrieved October 13, 2019, from https://kbbi.web.id/matrikulasi

Kemendikbud. (2014). Panduan Matrikulasi di SMA Tahun 2014. Jakarta.

Sunaiyah, S. (2018). Program Matrikulasi Pada Pembelajaran Kurikulum 2013. Indonesian Journal of Islamic Education Studies (IJIES), 1(1), Pp.115-133., 1(1), 115-133.

Syahadati, E., Rodhi, \& Sari, D. S. (2018). Persepsi Mahasiswa Terhadap Matrikulasi Mahasiswa Baru. Jurnal Pendidikan Bahasa, 7(1), 16-24.

Wulandari, E., Hapsari, R.A.F. and Ariany, D. (2013). Analisis Efektifitas Pelaksanaan Metode "Concept Map" Pada Matrikulasi Calon Mahasiswa Baru. Repository.Uinjkt.Ac.Id. 